\title{
Recarpeting a small college library:
}

\section{A practical approach}

\author{
By Nancy L. Herron \\ Head librarian, J. Clarence Kelly Library \\ Penn State University, McKeesport
}

\author{
and Ronald B. Servello
}

Manager, University Libraries Facilities

Planning and Maintenance Department

Penn State University, University Park

\section{How one team finished the job ahead of schedule.}

$\mathbf{T}$

he processes involved in recarpeting an academic library facility are complex and intensive, requiring extensive planning, communication, teamwork, patience, and dedication to the task on the part of the institution, the staff, the vendor, and even the users of the facility. One way to complete the installation successfully is to follow a standard approach to project management like the one used by the University Libraries of Penn State University in the recent recarpeting of the J. Clarence Kelly Library.

Concrete ideas are presented here in a practical approach to developing and executing a successful physical plant project composed of planning, implementation, and evaluation components. Although the academic library in this example (a twoyear college) is small by research library standards, universal caveats emerged that are helpful in achieving success with any library physical plant project that requires movement of a library collection. This article focuses on three major elements: 1) the moving and reassembling of a library collection at the same location; 2) the selection and installation of new carpet fabric and moldings in the facility; and 3) the impact of the project's interruption of library services on the structure of an electronic library network.

\section{The setting}

In the spring of 1990 , university funds became available to recarpet totally a branch campus library whose existing carpet was presenting a danger to users and a liability to Penn State University, a large land-grant institution offering graduate and undergraduate education. The facility, the J. Clarence Kelly Library, is one of 22 undergraduate libraries spread across the state. They comprise the University Library Network for the Commonwealth Educational System (CES) of Penn State.

The two-story building, constructed in 1972, provides approximately 14,500 square feet of space for library service and houses a collection of 60,000 volumes. It serves an undergraduate student population of 1,600, a faculty and staff of 110 , and the residents of two communities in the greater Pittsburgh area, White Oak Borough and the city of McKeesport.

\section{The project}

Examination of the recent literature of library move planners provided direction for developing a working plan. Articles by Bayne (1990), WeaverMeyers and Wasowski (1984), and Kurkel (1983), 
and chapters from Library Space Planning by Fraley and Anderson were invaluable in defining the scope of the project. ${ }^{1}$

In December 1989, when it became apparent that funding would be forthcoming from the university, the library administration established a project team consisting of the least number of people needed to execute the project. The team consisted of the following members: a project manager from the University Office of Physical Plant, the manager of the University Libraries Facilities Planning and Maintenance Department, the head librarian at the campus site, the director of business services, and the maintenance supervisor at the McKeesport campus. This group identified the following priorities:

1) establishing specifications;

2) defining the bid process;

3) setting a realistic timetable for the work;

4) deciding the best time to schedule the work;

5) defining lines of communication for dissemination of information regarding the project;

6) listing and assigning responsibilities.

These priorities provided a useful schema for the project. The specifications included a general description of the scope of the work including the furnishing of all labor, materials, tools, equipment, and services required to complete the replacement project of both floors of the building as described in the floor plan provided by the university. The work included removal of the existing floor covering and wall base molding; floor preparation for new carpet, accurate measurements and calculation of total yardage and material quantities requirements, supplying and installing the new carpet and wall base molding, coordinating the work sequence with movers; and dust and dirt protection and cleanup.

The institution included quality assurance specifications that required the installer to be responsible, dedicated to quality workmanship, and highly skilled and committed to the following: 1) punctuality with sufficient manpower to finish on

${ }^{1}$ Pauline S. Bayne, "The 'Do-it-yourself Move of a 1.5 Million-Volume Library," College and Research Libraries 51 (January 1990): 55-67; Pat Weaver-Meyers and Dale Francis Wasowski, "A Committee Approach to Moving a Library," Journal of Library Administration 89 (Winter 1984): 21-32; Donna Lee Kurkel, "The Planning, Implementation, and Movement of an Academic Library Collection," College and Research Libraries 44 (July 1983): 220-34; Ruth A. Fraley and Carol Lee Anderson, Library Space Planning: How to Assess, Allocate, and Reorganize Collections, Resources, and Physical Facilities (New York: NealSchuman, 1985), 89-132. schedule; 2) quickly resolving installation deficiencies; 3) completing the installation in accordance with the plans and specifications; 4) leaving the installation in the condition acceptable to the institution, specifier, and installer; and 5) quality workmanship always.

The institution required the contractor to submit for review samples (in the full color range currently available) of the carpet fabric and the vinyl wall base molding specified. The materials selected were to be stored in the loading dock area of the building, and all handling of materials was the responsibility of the installation contractor.

Library staff and users partially occupied the building during the construction. Constraints of labeling, moving and temporary storage of the library volumes dictated that the work would be performed in six stages:

- Stage 1 involved $1 / 3$ of main floor space, center section.

- Stage 2 involved $1 / 3$ of main floor space, left section.

- Stage 3 involved $1 / 3$ of main floor space, right section.

- Stage 4 involved 1/3 of lower floor space, center section.

- Stage 5 involved 1/3 of lower floor space, left section.

- Stage 6 involved $1 / 3$ of lower floor space, right section.

Cooperation with laborers doing the actual moving was of utmost importance because they had to free up installing space and alternate the newly recarpeted space as storage area for materials normally housed in new work areas. The sixstage plan by the manager of the University Libraries Facilities Planning and Maintenance Department provided for that

The installation contractor was required to submit to the university at the time of installation a letter on company letterhead and signed by an officer of the company stating the following five criteria:

1) That the installer guaranteed to relay or restretch any carpet that did not provide an attractive, wrinkle-free appearance and to correct any faulty installation condition which might appear within one year.

2) That the installer provided a manufacturer's unconditional guarantee that the carpet samples registered and the carpet proposed met or exceeded the specifications in every detail.

3) That the carpet manufacturer guaranteed all materials as first quality and guaranteed them against defects in workmanship and construction.

4) That the carpet manufacturer supplied the following warranties: ten-year wear warranty; tenyear fade warranty; five-year edge ravel warranty.

5) That the carpet manufacturer furnished a 
certificate verifying that the flammability requirements specified were met.

The university further required that carpet materials should meet construction specifications in regard to the following: description of fabric, weave, gauge, stitches, pile height, face yarn, yarn ply, face height, primary back, secondary back, total weight, dye method, density, weight density, static resistance, and flammability.

Other important elements include stipulation of field adhesive, seam adhesive, wall base molding, and wall base molding adhesive. These elements had to be spelled out in the contract along with the expected time of execution of the project including preparatory work, installation activities, final acceptance of responsibility by the contractor, and provision of attic stock or usable scrap materials packaged in appropriate wrapping, labeled, and delivered to the job site.

Once the plan was set, the team developed a formal specification for use by the University Purchasing Department in a request for competitive bids from qualified contractors. The work was advertised along with a listing of the contact agency, address of contact agency, and deadline for submission of bid. During the bidding process, the bidders were invited to visit the site. Ultimately, the success of the project was enhanced by the good fortune of having a reputable local vendor win the bid for the work.

\section{Setting a realistic timetable}

Since the project team decided that installation had to be completed in the three weeks between the close of the spring semester and the beginning of the summer session, the contractor had to build into the bid a proper amount of labor required to complete the project successfully within the time frame stipulated (one that guaranteed library service to support summer courses).

\section{Deciding the best time to scheale the work}

The contractor awarded the bid accomplished the work on schedule by providing two crews of workers, each working on different floors simultaneously. The university provided special equipment for moving the collection. Books were moved using large book trucks, each 30 wide $\leftrightarrow 18$ deep $\leftrightarrow 67$ high with a capacity of 288 linear inches of book space. These trucks each have six 6 pneumatic heavy capacity wheels, and the overall construction is heavy duty. A total of 25 of these trucks was sent from the University Park campus to the McKeesport campus just prior to the move. After the books were removed from each section, the shelves were either dismantled and moved out of the section, or they were simply slid out of the way. Any other furniture or equipment was also moved. Equipment sensitive to dust damage (photocopiers, computers, microforms, fax machines, etc.) was moved and stored in areas sealed off from the work areas.

Each work area defined in the six-stage plan was in turn prepared for carpeting by the contractor. The old carpet was lifted and discarded. The contractor provided strategically placed dumpsters, and materials were placed in them for pickup by a refuse company employed by the contractor. The surface was scarified and vacuumed to guarantee a firm bonding of new adhesive to new carpet backing. The new carpet was installed in long sheets cut to cover the large 1/3 portion of each floor area designated on the diagram of the floor plan. As each phase was completed, contractor personnel moved the shelves, books, furniture, and equipment back into their original locations.

The carpet chosen for the project was broadloom Antron 3, synthetic backed, level loop, and static controlled. These features insured long wear, stain resistance, water resistance, and reduced effects of static electricity on personal computers and terminals. Approximately 1,400 square yards of carpet were required for the job.

The new, regularly marketed adhesive chosen is non-toxic and low in odor. Special attention was paid to avoiding highly odorous, toxic adhesives because of their reportedly dangerous effects on pregnant women.

The successful bidder provided a contract design divided into four parts with each costed out separately. The parts included a bid for materials, installation, moving, and cleaning of the library after completion of the job. The cost for moving library materials was the most difficult to estimate, because the movers had never moved library shelving before and had no experience with the intricacies of reassembling the shelving. Problems with plumb-line and bracing often created double work. In the final analysis, contracting out for professional library shelving specialists to take down and reassemble the shelves would have been a worthwhile consideration.

One of the most important requirements in guaranteeing success with physical plant projects like this one is the definition of important communication lines for information sharing before, during, and after the completion of the project. Throughout the university organization, all users of library services needed to be informed well in advance of the proposed project. They needed to know when funding was provided. University and campus publications, signs, electronic bulletin boards all needed to be supplied with information regarding the project with special attention given to the possible interruption of library services at that 
location and at other locations that might be affected by a stop in interlibrary communicationinterlibrary loan, document delivery, etc. Faculty, too, needed to be prepared for a service interruption that might affect their research needs, course preparation, or reading schedules. Letters were sent to faculty and staff informing them of the suspension of library services during the project; an announcement was made at the final faculty meeting of the semester explaining the project and its implications for library service users. The librarian informed students and community users through the campus and local newspapers, giving them information about alternative libraries accessible during the interruption of campus library services. These libraries were contacted and alerted to the fact that Penn State users might be visiting their locations; reciprocal borrowing arrangements needed to be arranged.

Throughout the library network, other campuses needed to be informed of the closing of the library, especially those who might use the collection for interlibrary loan purposes. The electronic mail component of the online catalog was an excellent vehicle for this. It also simplified solicitation of advice from colleagues regarding past experiences with similar projects.

The most basic communication channel, the one most important to the success of the project, was the one established between the on-site library staff, the head librarian, and the local campus departments impacting on the execution of the work (business services, maintenance and janitorial services, and student services). This group held regular meetings to designate areas of responsibility, to plan, to implement, and to evaluate the stages of the project over a six-month period; regular work and information-gathering assignments were designed to guarantee a clear perception of what would take place during the project. Since library staff would be overseeing the reshelving of books, shelf-reading, and shifting of the collection, they needed to understand the work schedule and the time frames; they were considered a critical part of the total planning process from the outset.

\section{Assigning areas of responsibility}

All project team members needed to understand their areas of responsibility clearly. At the first meeting members defined the areas of responsibility as follows:

1) Project Manager, University Office of Physical Plant-provided input to the planning and implementation of physical plant matters e.g., specifications, bidding, awarding of contracts, inspection of work completed, payment for materials and services.
2) Manager, University Libraries Facilities Planning and Maintenance Department-was responsible for providing a detailed layout of the library before any moving of the collection or equipment took place. This was paramount to exact and precise replacement of items after completion of the recarpeting project. The manager was also responsible for developing the physical work plan and for securing approval of that plan from the Penn State Libraries administration.

3) Head librarian - the team designated the head librarian as the key person responsible for defining the project requirements. The coordination of the logistics of the project relative to library processes was the head librarian's responsibility, as was the coordination of library staff to oversee the work of movers in regard to the replacement of the collection. The library staff also was responsible for establishment of a temporary workstation to receive incoming mail, express mail deliveries, and United Parcel Service for document deliveries. Serials check-in was maintained, as was receipt of all new books from the processing center at the University Park campus. While no overdue library materials were accepted while the project endured, amnesty for library materials returned before and after the project was adopted and was well advertised to users.

4) Campus director of business servicesworked with campus security personnel, equipment installers, and vendors to guarantee that appropriate protection against theft or damage was in place during regular working hours as well as night and weekend hours when working overtime needed to be implemented to meet deadlines.

5) Campus maintenance and janitorial supervisor-provided janitorial support above that contracted for by the installer. Restroom maintenance and refuse pick-up continued during the term of the project as did monitoring and servicing of airconditioning units and elevators.

\section{Summary}

It took 21 workdays to dismantle the library, move the collection, lift the old carpet, scrape the floor free of old backing, apply new adhesive, install the new carpet and wall base molding, and reassemble the library. The job was completed three days ahead of schedule. The collections were moved shelf by shelf, cleaned, replaced, shelf-read, shifted, and readjusted before summer classes began. All furniture and equipment were moved and replaced throughout the library service areas, in offices, and in work spaces. Two work crews, consisting of three carpet installers and four laborers each, met schedules. Three library st aff workers supervised shelf moving and replacement. Three 
work-study students assisted with shelf reading, shifting, and replacement. However, it took six months of planning involving the project team, the contractor, the library staff, and experienced, welltrained, work-study students to make the project run on such a tight schedule. Good communication efforts throughout the university, within the University Libraries, and especially at the local campus site guaranteed smooth handling of the project for regular library users.
The impact of the project on the structure of the electronic library network serving the institution was minimized because planning and communication were done far in advance of the actual project. Alternatives were examined, and hackup was provided. Timing the project between the close of the spring semester and the start of summer session was critical to providing the shortest possible disruption of library services to students, faculty, and community.

\section{Delaware Valley Chapter activities}

The fall meeting of the Delaware Valley ACRL Chapter was held November 2, 1990, at the Arch Street Meeting House in Philadelphia. Approximately 80 librarians attended the all-day meeting on "Putting Performance Measures to Work." The program consisted of a series of speakers addressing theoretical and practical applications of measurement in academic libraries. Donald Farmer, vice president for academic affairs, King's College, Wilkes Barre, Pennsylvania, presented an inspiring talk about the positive impact assessment measures can have on higher education. Pat Kelly, assistant director, George Washington University Library, provided a general overview of performance meas- ures and introduced the recent ACRL publication entitled Measuring Academic Library Performance: A Practical Approach. A panel of speakers from the Louis L. Manderino Library, Califormia University of Pennsylvania, described practical applications of performance measures in their library, including a catalog study conducted before and after the implementation of the automated system. Betty Turock, associate professor, School of Communication, Information and Library Studies, and director of the MLS program, Rutgers University, ended the program with a theoretical overview of evaluation and described six common approaches to evaluation.

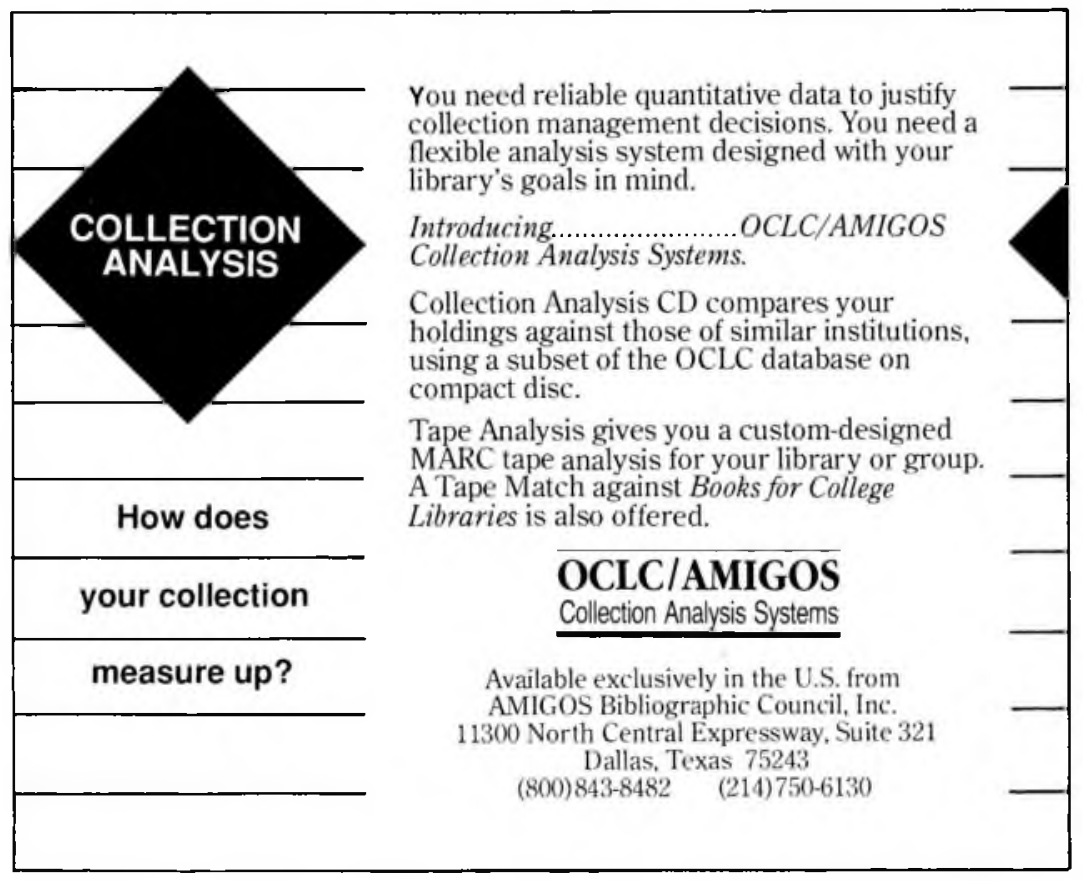




\section{$\$ 35,000$ archival administration 1991-1992 fellowships available}

The Records Program of the National Historical Publications and Records Commission is now accepting applications for three fellowships in archival administration. Jointly funded by the Commission and the Andrew W. Mellon Foundation, these fellowships will provide advanced administrative training in archives. For the 1991-1992 fellowship year, the stipend has been increased to $\$ 35,000$, plus up to $\$ 7,000$ in fringe benefits, for a nine- to twelvemonth period beginning between August and October 1991.

Fellows are provided with a series of administrative and decision-making experiences. In the past, these experiences have involved appraisal, budget preparation, personnel administration, publications, plant operation, longrange planning, disaster planning, collection policy development, and committee activities. The fellow is expected to complete some technical project, which often takes the form of a draft of some institutional policy.

Applicants should have between two and five years' experience in archival work. It is desirable, but not required, that applicants have the equivalent of two semesters of full-time graduate training in a program containing an archives education component.

Host institutions for the 1991-1992 fellowship will be: Oregon Office of the Secretary of State, Archives Division, Salem, Oregon; Regents of the University of California, University of California, Los Angeles; and Delaware Department of State, Division of Historical and Cultural Affairs, Bureau of Archives and Records Management, Dover, Delaware.

Fellowship application forms and more complete descriptions of the individual host programs should be requested from the NHPRC, National Archives Building, Washington, DC 20408; (202) 501-5610. The forms must be completed and received by the Commission by March 1, 1991.

Following the March 1, 1991, deadline, the Commission will provide the completed fellowship application forms to the host institutions, each of which will select a fellow by mid-June 1991. du Canada

\section{Canadiana Products from the National Library of Canada}

The National Library is responsible for promoting, gathering and preserving the published heritage of Canada. The Library has a vast collection of Canadiana dating from Canada's earliest days to the present. In order to provide access to Canada's published heritage the Library has developed various products which are invaluable to those with an interest in Canadian Studies or research.

The Library produces Canadiana, a comprehensive bibliography which documents the nation's published heritage. Canadiana is a valuable aid for Canadian Studies and is available in printed and microfiche formats and on magnetic tape.

- Canadiana authorities lists verified name headings of Canadian origin and can help in compiling bibliographies and answering research and reference questions.

- Canadian Theses is a microfiche bibliography of masters' and doctoral theses accepted by Canadian universities, as well as selected foreign theses of Canadian authorship or interest.

- DOBIS is a Canadian online library system that provides access to the collections of many Canadian libraries via its continuously updated Canadian Union Catalogue of more than 5000000 bibliographic records.

For more information or a descriptive brochure on these products please contact:

National Library of Canada

395 Wellington Street

Ottawa, Canada

KIA ON4 